\title{
Late Quaternary Antarctic sea-ice history: Evidence from deep-sea sediment records
}

\section{Xavier Crosta}

Université Bordeaux I, France: x.crosta@epoc.u-bordeaux1.fr

In the Southern Ocean, sea-ice (frozen surface seawater) surrounds the Antarctic continent, covering $4.10^{6} \mathrm{~km}^{2}$ in summer and $20.10^{6} \mathrm{~km}^{2}$ in winter (Gloersen et al., 1992). This pronounced seasonal cycle strongly affects the climate of the Southern Hemisphere through its impacts on the energy and gas budget, atmospheric circulation, hydrological cycle and biological productivity. Sea ice also modulates the climate of more remote regions through its impact on deep and intermediate oceanic circulations.

Sea ice is a very dynamic environment and has varied considerably in its extent through time. Whaling ship records (de la Mare, 1997), satellite measurements (Cavalieri et al., 2003) and ice-core data (Curran et al., 2003) indicate that Antarctic sea-ice underwent a dramatic decrease in maximum extent from the 1950 's. Acceleration of this reduction, as a result of future global warming, may have important feedbacks on future climate. However, sea ice is still not well computed in climatic models because of its complicated relationship with climate changes over a large range of timescales. One way to ameliorate our understanding of such relationship is to reconstruct sea-ice extent over long and key time periods for which the global climate is known. These reconstructions, started in the early 1980 's, are still very sparse in both number and coverage due to the scarcity of good sediment sequences in the Southern Ocean.

Here, we present three records from the Atlantic and Indian sectors of the Southern Ocean that provide information on sea-ice dynamics over the last two climatic cycles. These records have enabled the development of a map of winter and summer sea-ice extent at the Last Glacial Maximum (LGM), documenting sea-ice distribution in a very different global climatic state.

\section{Long records}

Records of sea-ice extent result almost exclusively from the investigation of fossil diatom assemblages preserved in deep-sea sediments. Some Antarctic species show a strong affinity to sea ice (Horner, 1985) and are, therefore, most useful in estimating paleo sea-ice cover.

Fossil sea-ice diatoms can be used qualitatively to estimate past seasonal

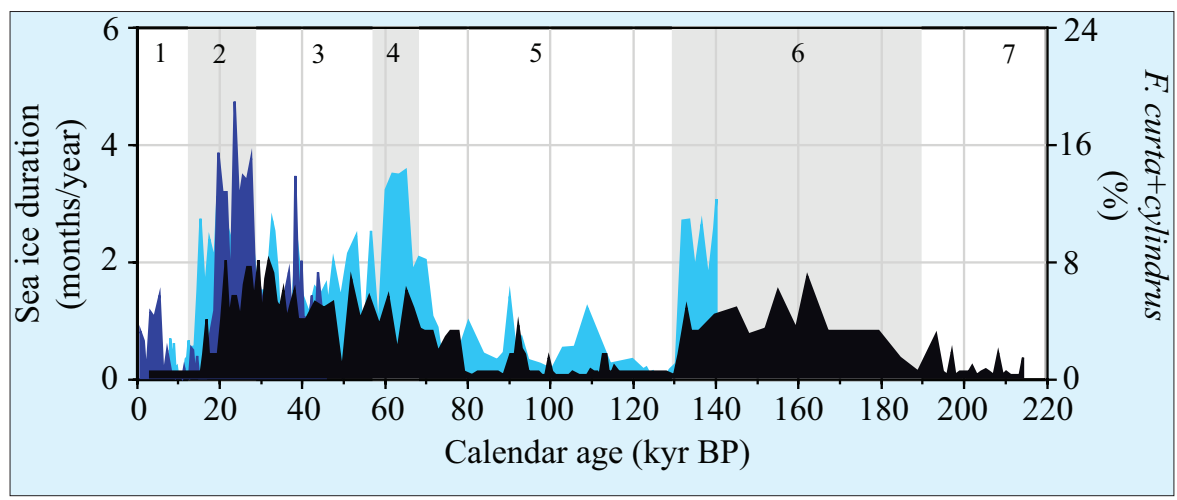

Figure 1: Sea-ice history over the last $220 \mathrm{kyr}$ BP. Sea-ice duration was estimated by MAT in core SO136-111 from the east Indian sector of the Southern Ocean (black) and in core TNO57-13PC4 from the Atlantic Sector of the Southern Ocean (dark blue). Sea-ice duration is compared to relative abundances of F. curta + cylindrus proxy of sea-ice presence in core PS1768-8 (light blue). Core SO136-111 covers the last 220 kyr BP, core TNO57-13PC4 covers the last $40 \mathrm{kyr}$ BP and core PS1768-8 covers the last $140 \mathrm{kyr}$ BP. Odd numbers and white areas represent interglacial stages, while even numbers and shaded areas represent glacial stages.

sea-ice extent. Abundance of Fragilariopsis curta and F. cylindrus greater than $3 \%$ denotes a recurrent presence of seasonal winter sea ice, while abundance of F. obliquecostata greater than $3 \%$ denotes the recurrent presence of summer sea ice at the core location (Gersonde and Zielinski, 2000). Increasing abundances of these taxa indicate greater sea-ice cover. Fossil diatoms can also be used quantitatively, based on a statistical treatment of 30 diatom species including sea-ice taxa and open-ocean taxa (Crosta et al., 1998a). The Modern Analogue Technique (MAT) compares the fossil diatom assemblages to a set of core-top diatom assemblages with known modern surface conditions that are subsequently used to attribute the fossil sample with an estimate of sea-ice duration in number of months per year.

Long records of Antarctic sea-ice extent are rare and are to date restricted to the Atlantic and Indian sectors. Three records, one from the east Indian sector (core S0136-111, black curve in Fig. 1), and two from the Atlantic sector (core TN057-13PC4, dark blue curve in Fig. 1; core PS1768-8, light blue curve in Fig. 1) are presented here. Sea-ice conditions at core locations SO136-111 and TNO5713PC4 were estimated by MAT (Crosta et al., 2004; Stuut et al., 2004), while winter sea-ice conditions at site PS1768-8 were documented by relative abundances of F.curta+cylindrus (Gersonde and Zielinski, 2000).

These three records give a very coherent picture of sea-ice advance and retreat around Antarctica during the Late Quaternary, although the amplitude of sea-ice changes are more important in the Atlantic sector (Fig. 1) in relation to the presence of the Weddell Gyre promoting northward ice transport. The cores are today a few degrees of latitude northward of the winter sea-ice edge (Fig. 2) and were similarly ice-free during other warm periods such as the Marine Isotopic Stages (MIS) 5 and 7. Winter sea-ice extent during these periods was certainly very comparable to today's extent. At interglacial-glacial transitions, sea ice advanced very rapidly to reach its full glacial extent within a few thousand years (Fig. 1). The two longest records (SO136-111 and PS1768-8) indicate that sea-ice conditions were certainly comparable during every glacial stage of the last 220 kyr BP. During glacial-interglacial transitions, sea ice retreated very rapidly — within a few thousand years - to its modern position.

Sea-ice advance and retreat are initiated by variations in atmospheric and oceanic temperature and, due to the very reactive nature of sea ice, reaches full glacial or full interglacial conditions before the completion of the temperature change (Bianchi and Gersonde, 2002; 2004). Conversely, variations in sea-ice cover during full glacial conditions are linked to feedback processes in wind stress and atmospheric temperatures. This finding is also confirmed by investigations of chemical tracers in ice cores (Wolff et al., 2006).

\section{Last Glacial Maximum}

In the early 1980's, tremendous effort was applied to reconstruct global conditions of the Earth at the LGM (CLIMAP, 1981). For the Southern Ocean, the effort centered 
on estimating sea-surface temperatures via a radiolarian-based transfer function, and winter and summer sea-ice limits via a combination of micropaleontological and lithological tracers. According to CLIMAP (1981), the winter sea-ice edge was 5-10 of latitude northward of its modern position, overlying the modern Antarctic Polar Front (Fig. 2), due to colder air and sea-surface temperatures and more intense winds. The winter sea-ice cover at the LGM was, therefore, twice the modern surface. Similarly, the LGM summer sea-ice edge was projected northward of its modern position, overlying the modern winter sea-ice margin (Fig. 2). The summer sea-ice cover was, therefore, 6-7 times greater than modern extent. A huge permanently covered area was estimated, which is likely to have greatly affected the southern hemisphere climate. For example, paleoclimatic models attribute the Southern Ocean with a 70 ppm impact on atmospheric $\mathrm{CO}_{2}$ out of the $80 \mathrm{ppm}$ drop observed on glacialinterglacial timescale when CLIMAP seaice limits are introduced as boundary conditions (Stephens and Keeling, 2000).

The CLIMAP (1981) LGM summer sea-ice extent was quickly found to also represent spring sea-ice extent (Burckle et al., 1982). However, no proxy was calibrated to document summer sea-ice cover until the development of diatom-based transfer function in the late 1990's, which established the relationship between diatoms and surface conditions (Zielinski and Gersonde, 1997; Crosta et al., 1998a). As part of the MARGO initiative (Multiproxy Approach for the Reconstruction of the Glacial Ocean surface), diatom assemblages confirmed a doubling of the winter sea-ice cover at the LGM, mainly due to the progression of the compacted sea ice (Burckle and Mortlock, 1998; Crosta et al., 1998b). The surface covered by sea ice was estimated to be around $43.5 \times 10^{6}$ $\mathrm{km}^{2}$. Conversely, diatom assemblages argue for a more restricted summer sea-ice cover than estimated by CLIMAP (1981), with surfaces around $11 \times 10^{6} \mathrm{~km}^{2}$ and 30 $x 10^{6} \mathrm{~km}^{2}$ (Fig. 2), respectively. In the Atlantic sector, off the Weddell Sea, the glacial summer sea-ice margin was certainly displaced northward to overlie the modern Antarctic Polar Front (Armand and Leventer, 2003). A similar situation was probably occurring in the western Pacific off the Ross Sea. In the Indian and the eastern Pacific, glacial summer sea-ice cover was certainly comparable to modern conditions prevailing in these sectors. Similar conditions existed in the glacial Northern Hemisphere. LGM winter sea-ice cover was greatly expanded, while summer sea-ice

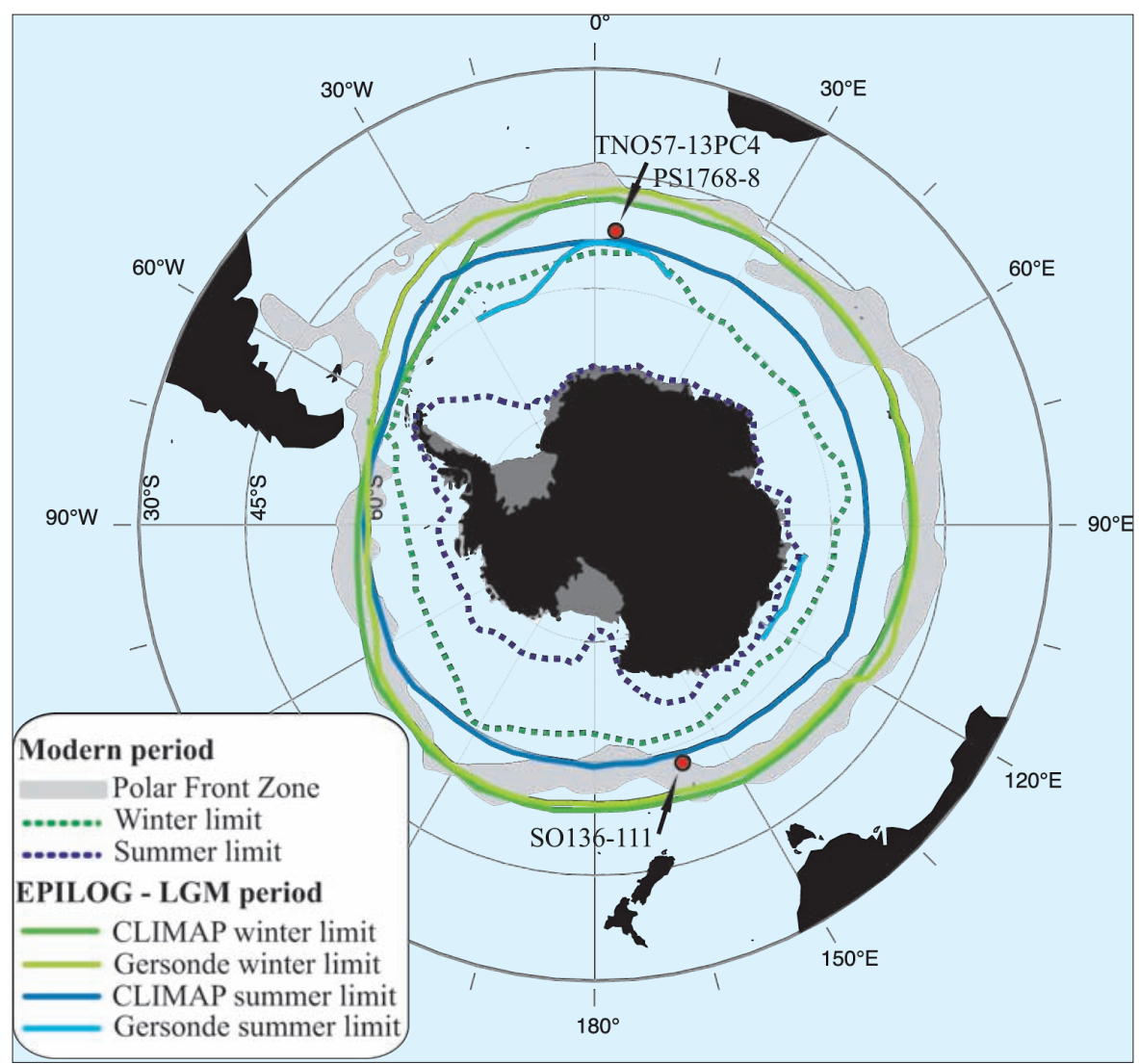

Figure 2: Comparison of LGM winter and summer sea-ice edge reconstructions by CLIMAP (1981) and Gersonde et al. (2005) with modern winter and summer sea-ice edges (Schweitzer, 1995).

cover was comparable to today (de Vernal and Hillaire-Marcel, 2000). Paleoclimatic models estimate a 5-30 ppm impact of Antarctic sea-ice cover on the glacial atmospheric $\mathrm{CO}_{2}$ drop when diatom-based sea-ice extent and concentration data are used as boundary conditions (MoralesMaqueda and Rahmstorf, 2002; Bopp et al., 2003). Although Antarctic sea ice and, more globally the Southern Ocean, is certainly a key component in regulating atmospheric $\mathrm{CO}_{2}$ variations and, therefore, climate changes, it cannot alone explain glacial-interglacial changes in $\mathrm{pCO}_{2}$ that are rather dependant upon the feedback of several components of the internal climatic system.

\section{Conclusion}

Despite its importance in global climate changes, Antarctic sea-ice extent during the Late Quaternary has been rarely documented, partly because few proxies are developed to estimate sea-ice past conditions and partly because of the lack of good sediment records. This is particularly true for the Pacific sector of the Southern Ocean. In comparison to the Northern Hemisphere, very few microorganisms are abundant and well preserved in Southern Ocean sediments. From the oceanic perspective, diatoms are the ultimate reconstructive tool. Chemical tracers preserved in ice cores give additional information from the atmospheric perspective (Wolff et al., 2006). The combination of geological and glacial records will greatly improve our knowledge on paleo sea-ice dynamics, which is of great importance in paleoclimatic models. New geochemical proxies, such as the highly branched isoprenoids (Johns et al., 1999) may emerge in the future. However, this tool is today restricted to coastal Antarctic areas where concentrations in the sediment are sufficiently high.

\section{References}

Crosta, X., Pichon, J.J. and Burckle, L.H., 1998a: Application of modern analogue technique to marine Antarctic diatoms: Reconstruction of the maximum sea ice extent at the last glacial maximum, Paleoceanography, 13(3): 284-297.

Gersonde, R. and Zielinski, U., 2000: The reconstruction of Late Quaternary Antarctic sea-ice distribution - The use of diatoms as a proxy for sea-ice, Palaeogeography Palaeoclimatology Palaeoecology, 162: $263-286$

Gersonde, R., Crosta, X., Abelmann, A. and Armand, L.K., 2005: Sea surface temperature and sea ice distribution of the last glacial. Southern Ocean - A circum-Antarctic view based on siliceous microfossil records, Quaternary Science Reviews, 24: 869-896.

Morales-Maqueda, M.A. and Rahmstorf, S., 2002: Did Antarctic sea-ice expansion cause glacial $\mathrm{CO}$ decline?, Geophysical Research Letters, 29(1): 1011, doi: 10.1029/2001GL013240.

Wolff, E., Fisher, H., Fundel, F., Ruth, U., Twarloh, B., Littot, G.C., Mulvaney, R., Röthlisberger, R., de Angelis, M., Boutron, C.F., Hansson, M. Jonsell, U., Hutterli, M.A., Lambert, F., Kaufmann, P., Stauffer, B., Stocker, T.F., Steffensen, J.P., Bigler, M., Siggaard-Andersen, M.L., Udisti, R., Becagli, S., Castellano, E., Severi, M., Wagenbach, D. Barbante, C., Gabrielli, P. and Gaspari, V., 2006: Southern Ocean sea-ice extent, productivity and iron flux over the past eight glacial cycles, Nature, 440: 491-496.

For full references please consult:

www.pages-igbp.org/products/newsletter/ref2007_2.htm | 